\title{
PENGARUH PEMBELAJARAN BERBASIS MASALAH DENGAN SETTING KOOPERATIF JIGSAW TERHADAP KEMANDIRIAN BELAJAR SISWA SMA
}

Oleh:

\author{
Asep Ikin Sugandi \\ Pendidikan Matematika STKIP Siliwangi Bandung \\ asepikinsugandi@yahoo.co.id
}

\begin{abstract}
Kemandirian belajar merupakan aspek yang sangat penting dalam pembelajaran matematika. Hal ini didasarkan bahwa indikator kemandirian belajar seperti 1) Inisiatif Belajar, 2). Mendiagnosa Kebutuhan Belajar, 3) Menetapkan Target dan Tujuan Belajar, 4) Memonitor, Mengatur dan Mengontrol, 5) Memandang Kesulitan Sebagai Tantangan, 6) Memanfaatkan dan Mencari Sumber yang relevan, 7) Memilih dan Menerapkan Strategi Belajar, 8) Mengevaluasi Proses dan Hasil Belajar dan 9) Self Eficacy (konsep diri) sesuai dan mendukung dengan penerapan pendekatan berbasis masalah dengan seting kooperaif Tipe Jigsaw.
\end{abstract}

Kata Kunci : Kemandirian Belajar, Berbasis Masalah, Jigsaw

Independent learning is a very important aspect in learning mathematics. This is based on independent learning indicators such as 1) Learning Initiative, 2). Diagnosing Learning Needs, 3) Setting Targets and Goals Learning, 4) Monitor, Manage and Control, 5) Difficulties Looking For Challenges, 6) Utilize and Finding the relevant sources, 7) Choosing and Implementing Strategy Study, 8) Evaluating the Process and Results learning and 9) self Eficacy (self-concept) compliant and supports the implementation of problembased approach to setting kooperaif Jigsaw type.

Key words : Independence Learning, Problem Based, Jigsaw

\section{Latar Belakang Masalah}

Kemandirian belajar siswa perlu dikembangkan karena kemandirian belajar siswa merupakan hal yang turut menentukan berhasilnya pengimplementasian pembelajaran berbasis masalah dengan setting kooperatif tipe Jigsaw dan turut menentukan pencapaian hasil belajar siswa, hal ini cukup beralasan karena pembelajaran yang menciptakan situasi pemecahan masalah sangat diperlukan kemandirian siswa dalam belajar. Kemandirian belajar adalah suatu sikap siswa yang memiliki karakteristis berinisiatif belajar; mendiagnosis kebutuhan belajar; menetapkan tujuan belajar; memonitor, mengatur dan mengontrol kinerja atau belajar; memandang kesulitan sebagai tantangan; mencari dan memanfaatkan sumber belajar yang relevan; memilih dan menerapkan strategi belajar; mengevaluasi proses dan hasil belajar; serta self-concept (konsep diri). 
Siswa yang berada pada level sekolah tinggi diasumsikan memiliki kemandirian belajar yang lebih tinggi dibandingkan dengan siswa yang berada pada level sekolah sedang. Siswa yang berada pada level sekolah tinggi lebih mampu mengatur waktu dan mengontrol diri dalam berpikir, merencanakan strategi, kemudian melaksanakannya, serta mengevaluasi atau mengadakan refleksi. Hal ini didukung oleh hasil studi Darr dan Fisher (2004) yang melaporkan bahwa kemampuan belajar mandiri berkorelasi tinggi dengan keberhasilan belajar siswa

Salah satu alternatif pendekatan pembelajaran yang diprediksi dapat efektif dalam meningkatkan kemandirian belajar adalah Pembelajaran Berbasis Masalah dengan setting pembelajaran Kooperatif tipe Jigsaw. Alasan mengapa memilih Pembelajaran Berbasis Masalah dengan setting pembelajaran Kooperatif tipe Jigsaw diantaranya dengan menyajikan masalah kontekstual pada awal pembelajaran merupakan salah satu stimulus dan pemicu siswa untuk berpikir. Hal ini menuntut siswa untuk memiliki sifat mandiri dalam belajar sehingga ia tidak akan merasa putus asa dalam menghadapi masalah dan mendorong siswa untuk memilih strategi yang cocok unuk menyelesaikan masalah tersebut

Alasan lain, melalui pembelajaran dengan berbasis masalah dengan setting pembelajaran kooperatif tipe Jigsaw, siswa juga belajar untuk bertanggung jawab dalam kegiatan belajar, tidak sekedar menjadi penerima informasi yang pasif, namun harus aktif mencari informasi yang diperlukan sesuai dengan kapasitas yang ia miliki. Dalam PBM dengan setting kooperatif tipe Jigsaw siswa dituntut untuk terampil bertanya dan mengemukakan pendapat, menemukan informasi yang relevan dari sumber yang tersembunyi, mencari berbagai cara alternatif untuk mendapatkan solusi, dan menentukan cara yang paling efektif untuk menyelesaikan masalah. Hal inilah yang sesuai dengan sifat-sifat yang ada dalam kemandirian belajar

Mengingat matematika adalah ilmu yang terstruktur maka untuk menguasai suatu konsep matematika diperlukan penguasaan konsep dasar matematika lainnya, maka kemampuan kognitif awal siswa yang dinyatakan dalam tingkat kemampuan awal siswa (TKAS) terhadap matematika memegang peranan yang sangat penting untuk penguasaan konsep baru matematika.

Selain faktor TKAS, faktor level sekolah (Tinggi, Sedang dan Rendah) perlu diperhatikan dalam mengembangkan Kemampuan berpikir matematis tingkat tinggi dan kemandirian belajar siswa . Hal ini dilakukan supaya terwakili sekolah yang ada baik segi kualitas maupun dari segi kemampuan siswa.

Selain itu penentuan level sekolah didasarkan kepada fasilitas yang dimiliki oleh sekolah. Fasilitas tersebut antara lain gedung, alat pelajaran baik yang dipakai oleh guru pada waktu mengelola pembelajaran, maupun yang dipakai oleh siswa untuk 
menerima bahan yang diajarkan itu. Alat pelajaran tersebut seperti buku-buku diperpustakaan, labotarium, atau media-media pembelajaran lain yang digunakan sebagai alat bantu dalam pembelajaran. Alat pengajaran yang lengkap dan tepat akan memperlancar penerimaan bahan pelajaran yang diberikan kepada siswa. Jika siswa mudah menerima pelajaran dan menguasainya maka siswa akan termotivasi untuk belajar lebih giat lagi. Oleh karena itu untuk menciptakan proses pembelajaran yang mampu mengoptimalkan potensi siswa, faktor level sekolah perlu menjadi salah satu bahan pertimbangan.

Memperhatikan uraian di atas, penulis tedorong untuk melakukan penelitian yang memfokuskan pada penerapan model pembelajaran berbasis masalah dengan setting kooperatif tipe Jigsaw dalam upaya mengembangkan kemandirian belajar siswa Sekolah Menengah Atas ditinjau dari level sekolah dan pengetahuan awal matematika siswa.

\section{Kajian Teori}

Para ahli psikologi memberikan pengertian kemandirian belajar yang beragam, diantaranya pendapat Knain dan Turmo (Ratnaningsih, 2007 : 38) yang dimaksud kemandirian belajar adalah suatu proses yang dinamik dimana siswa membangun pengetahuan, keterampilan, dan sikap pada saat mempelajari konteks yang spesifik. Untuk itu siswa perlu memiliki berbagai strategi belajar, pengalaman menerapkannya dalam berbagai situasi, dan mampu merefleksi secara efektif. Kemudian, Wolters, Pintrich, dan Karabenick (Ratnaningsih, 2007 : 38) menegaskan bahwa kemandirian belajar adalah suatu proses konstruktif dan aktif dimana siswa menentukan tujuan dalam belajar, dan mencoba untuk memonitor, mengatur, dan mengendalikan kognisi, motivasi, dan perilaku dengan dibimbing dan dibatasi oleh tujuan dan karakteristik kontekstual dalam lingkungan.

Selanjutnya Montalvo dan Torres (Sumarmo, 2004) memberikan pengertian kemandirian belajar yaitu gabungan antara keterampilan dan kemauan. Demikian pula menurut Sumarmo (2004: 1) kemandirian belajar merupakan proses perancangan dan pemantauan diri yang seksama terhadap proses kognitif dan afektif dalam menyelesaikan suatu tugas akademik. Dalam hal ini, Hargis (Sumarmo, 2004: 1) menekankan bahwa yang dimaksud kemandirian belajar bukan merupakan kemampuan mental atau keterampilan akademik tertentu, tetapi merupakan proses pengarahan diri dalam mentransformasi kemampuan mental ke dalam keterampilan akademik tertentu.

Bandura (Sumarmo, 2004: 2) mengidentifikasi karakter kemandirian belajar yaitu: mengamati dan mengawasi diri sendiri, membandingkan posisi diri dengan standar tertentu, dan memberikan respon sendiri (respon positif dan respon negatif). Paris dan Winograd (Sumarmo, 2006 : 12) menegaskan, tiga karakteristik utama dari 
kemandirian belajar yaitu kesadaran berpikir, penggunaan strategi, dan motivasi yang terpelihara.

Selanjutnya, Paris dan Winograd (Ratnaningsih, 2007 : 39) merinci dua belas kemandirian belajar ke dalam empat kategori:

1. Menilai diri mengarah pada pemahaman belajar yang lebih dalam.

Menilai diri secara periodik akan bermanfaat bagi guru dan siswa, karena merupakan refleksi pada pembelajaran yang dinamik.

a. Menganalisis gaya dan strategi belajar, membandingkannya dengan yang lain, meningkatkan kesadaran akan cara-cara belajar yang berbeda.

b. Mengevaluasi apa yang diketahui dan apa yang tidak diketahui, melihat kedalaman pemahaman tentang pokok-pokok materi, mempromosikan upaya yang efisien.

c. Penilaian diri dari proses belajar dan out-come secara periodik, adalah suatu kebiasaan yang bermanfaat untuk dikembangkan, karena akan meningkatkan pengendalian kemajuan, menstimulasi strategi yang diperbaiki, dan meningkatkan perasaan self-efficacy.

2. Mengatur diri dalam berpikir, berupaya, dan meningkatkan pendekatan yang fleksibel pada pemecahan masalah yang adaptif (menyesuaikan diri), tekun, pengendalian diri, strategis, dan berorientasi tujuan.

a. Mentargetkan tujuan yang sesuai dan dapat dicapai tetapi menantang, paling efektif dipilih siswa.

b. Mengatur waktu dan sumber-sumber melalui perencanaan yang efektif dan pengontrolan, merupakan faktor penting dalam mengatur prioritas, mengatasi frustasi, dan dengan tekun menyelesaikan tugas.

c. Mereviu belajar sendiri, merevisi pendekatan, atau bahkan memulai sesuatu dari yang baru, memonitor diri dan komitmen pribadi untuk mencapai kinerja standar tinggi.

3. Self-regulation dapat diajarkan dengan berbagai cara.

Self-regulation dapat diajarkan dengan pengajaran secara eksplisit, refleksi langsung, dan diskusi metakognisi; dapat ditingkatkan secara tidak langsung, dengan pemodelan dan aktivitas yang memerlukan analisis reflektif dari belajar, mengevaluasi, membuat peta, dan mendiskusikan bukti-bukti dari pertumbuhan seseorang; terpilih dalam pengalaman naratif dan identitas dari setiap individual.

4. Belajar adalah bagian dari kehidupan seseorang, dan sebagai akibat dari karakter seseorang. Dengan pandangan ini, kemandirian belajar dibangun oleh karakter dari kelompok yang diikutinya.

a. Bagaimana individu memilih untuk menilai dan memonitor perilaku mereka, umumnya konsisten dengan identitas yang mereka pilih dan inginkan. 
b. Memperoleh perspektif sendiri pada pendidikan dan belajar, menyediakan suatu kerangka kerja naratif, yang akan memperdalam kesadaran pribadi dari self-regulation.

c. Partisipasi dalam suatu komunitas yang reflektif akan meningkatkan banyak dan kedalaman pengujian kebiasaan self-regulation seseorang.

Zimmerman (Ratnaningsih, 2007 : 40) dengan ungkapan yang agak berbeda, bahwa kemandirian belajar meliputi tiga fase utama yang berulang yaitu: forethought (pikiran sebelumnya atau sesudahnya), performance control (mengontrol kinerja), dan self-reflection (refleksi diri). Forethought melibatkan menganalisis tugas dan mengatur tujuan yang dikehendaki. Performance control mengacu pada memonitor dan mengontrol tindakan kognitif, sikap, emosi dan motivasi, yang mempengaruhi kinerja. Self-reflection berkaitan dengan membuat pertimbangan tentang apa yang telah dicapai dan merubah perilaku dan orientasi tujuan, apabila diperlukan. Pendapat yang sejalan dengan Zimmerman di atas, menurut Schunk dan Zimmerman (Sumarmo, 2004: 2) terdapat tiga phase utama dalam siklus kemandirian belajar yaitu: merancang belajar, memantau kemajuan belajar selama menerapkan rancangan, dan mengevaluasi hasil belajar secara lengkap. Kegiatan masing-masing tahapan menurut Schunk dan Zimmerman dirinci sebagai berikut:

1. Merancang belajar meliputi kegiatan: menganalisis tugas belajar, menetapkan tujuan belajar, dan merancang strategi belajar.

2. Memantau kemajuan belajar merupakan kegiatan dengan mengajukan pertanyaan kepada diri sendiri: apakah strategi yang dilaksanakan sesuai dengan rencana, apakah saya kembali pada kebiasaan lama, apakah saya tetap memusatkan diri, dan apakah strategi yang telah direncanakan berjalan dengan baik.

3. Mengevaluasi hasil dilakukan melalui pertanyaan: apakah strategi telah dilaksanakan dengan baik (evaluasi proses), hasil belajar apa yang telah dicapai (evaluasi produk), dan sesuaikah strategi dengan jenis tugas belajar yang dihadapi.

Apabila kita perhatikan pengertian kemandirian belajar di atas dan aspek-aspeknya, meskipun para ahli memberikan penjelasan yang agak berbeda, tetapi semuanya memuat tiga karakteristik utama yang serupa yaitu: individu merancang belajarnya sendiri sesuai dengan keperluan atau tujuan individu yang bersangkutan, individu memilih strategi dan melaksanakan rancangan belajarnya, kemudian individu memantau kemajuan belajarnya sendiri, mengevaluasi hasil belajarnya dan dibandingkan dengan standar tertentu (Sumarmo, 2004: 4).

Masing-masing individu mempunyai tingkat kemandirian belajar yang bervariasi, tetapi belum ada aturan yang baku untuk menentukan hal itu. Pendapat Tillmann dan Weiss (Ratnaningsih, 2007 : 41) bahwa siswa dikatakan mandiri dalam belajar, jika yang bersangkutan memiliki kemampuan untuk mengembangkan pengetahuan, 
keterampilan, dan sikap, yang meningkatkan dan memfasilitasi belajar selanjutnya dan juga mengabstraksi pengetahuan yang diperoleh untuk dapat ditransfer pada situasi belajar yang lain. Masih menurut Tillmann dan Weiss (2000) siswa dikatakan mandiri dalam belajar pada tingkatan perilaku jika memilih, menyusun, dan menciptakan lingkungan sosial dan material secara aktif yang akan mengoptimalkan proses belajarnya; kemudian siswa dikatakan mandiri dalam belajar pada aktivitas metakognitif jika merencanakan, mengorganisasikan, dan mengevaluasi secara terus-menerus.

Demikian pula pendapat Yang (Sumarmo, 2004 : 12) siswa yang memiliki kemandirian belajar yang tinggi cenderung belajar lebih baik dalam pengawasannya sendiri dari pada dalam pengawasan program; mampu memantau, mengevaluasi, dan mengatur belajarnya secara efektif; menghemat waktu dalam menyelesaikan tugasnya; dan mengatur belajar dan waktu secara efisien.

Lebih lanjut Sumarmo (2004) mengutarakan tentang indikator dalam kemandirian belajar sebagai berikut :

1) Inisiatif Belajar,

2) Mendiagnosa Kebutuhan Belajar,

3) Menetapkan Target dan Tujuan Belajar,

4) Memonitor, Mengatur dan Mengontrol,

5) Memandang Kesulitan Sebagai Tantangan,

6) Memanfaatkan dan Mencari Sumber yang relevan,

7) Memilih dan Menerapkan Strategi Belajar,

8) Mengevaluasi Proses dan Hasil Belajar,

9) Self Eficacy (konsep diri)

\section{Rumusan Masalah}

Berdasarkan latar belakang masalah yang telah diuraikan di atas, maka rumusan masalah dalam penelitian ini sebagai berikut :

1. Bagaimana pencapaian kemandirian siswa berdasarkan pendekatan pembelajaran, level sekolah dan tingkat kemampuan awal siswanya?

2. Apakah terdapat interaksi antara pendekatan pembelajaran dan level sekolah terhadap kemampuan kemandirian belajar siswa dalam matematika?

3. Apakah terdapat interaksi antara pendekatan pembelajaran dan Tingkat Kemampuan Awal Siswa (TKAS) terhadap kemandirian belajar siswa dalam matematika? 


\section{Metode dan Desain Penelitian}

Metode dalam Penelitian ini adalah Kuasi Eksperimen karena adanya manipulasi perlakuan, sedangkan disain penelitiannya sebagai berikut :

$\begin{array}{ll}\mathrm{X}_{1} & \mathrm{O} \\ \mathrm{X}_{2} & \mathrm{O} \\ & \mathrm{O}\end{array}$

Keterangan :

$\mathrm{X}_{1}$ : Pembelajaran Berbasis Masalah (PBM) dengan setting Koperatif tipe Jigsaw

$\mathrm{X}_{2}$ : Pembelajaran Berbasis Masalah (PBM)

$\mathrm{O}$ : Tes Kemampuan Berpikir Matematis Tingkat Tinggi

Populasi dalam penelitian ini adalah seluruh siswa di tiga SMA yang mewakili Sekolah level tinggi, sedang dan rendah. Subyek sampel adalah siswa kelas XI Program IPA dari tiga SMA tersebut. Dari tiap-tiap sekolah yang mewakili level sekolah tinggi, sedang dan rendah diambil tiga kelas secara acak dari 5 kelas yang ada. Instrumen yang digunakan berupa soal-soal KBMTT sedangkan untuk kemandirian belajar menggunkan skala Likert (Skala Likert yang digunakan merupakan hasil Prof. Dr. Utari Sumarmo)

\section{Analisis Data Penelitian}

\section{Deskripsi Kemandirian Belajar Siswa dalam Matematika}

Deskripsi kemandirian belajar siswa dalam matematika merupakan gambaran kualitas kemandirian belajar siswa dalam matematika secara keseluruhan, berdasarkan jenis pendekatan pembelajaran (pendekatan pembelajaran BMJ, BM dan pendekatan pembelajaran KV), peringkat sekolah (Tinggi, sedang dan rendah), dan Tingkat kemampuan awal matematika siswa (TKAS) kelompok baik, sedang atau bawah. Deskripsi yang dimaksud adalah rata-rata, simpangan baku, dan jumlah siswa berdasarkan pendekatan pembelajaran, peringkat sekolah, dan klasifikasi Tingkat kemampuan awal matematika siswa (TKAS).

Data kemandirian ini didapat dari hasil pengolahan angket yang ditulis dalam bentuk skala Likert dengan 4 opsion, yaitu sangat setuju, setuju, tidak setuju dan sangat tidak setuju. Adapun indikator dalam penyusunan angket ini adalah : berinisiatif belajar; mendiagnosis kebutuhan belajar; menetapkan tujuan belajar; memonitor, mengatur dan mengontrol kinerja atau belajar; memandang kesulitan sebagai tantangan; mencari dan memanfaatkan sumber belajar yang relevan; memilih dan menerapkan strategi belajar; mengevaluasi proses dan hasil belajar; serta self-konsep (konsep diri). Angket ini diberikan setelah siswa mendapatkan perlakuan berupa pengajaran berbasis masalah dengan setting kooperatif tipe Jigsaw $(\mathrm{BMJ})$, pengajaran berbasis masalah (BM) dan pembelajaran konvensional. 
Untuk lebih jelasnya pada Tabel 1 dikemukakan deskripsi kemandirian belajar siswa dalam matematika yang diperoleh dari hasil angket sebagai berikut :

Tabel 1

Deskripsi Kemandirian Belajar Siswa dalam Matematika Berdasarkan Pendekatan Pembelajaran, Peringkat Sekolah, dan TKAS

\begin{tabular}{|c|c|c|c|c|c|c|c|c|c|c|c|c|c|}
\hline \multirow{3}{*}{$\begin{array}{l}\mathrm{L} \\
\mathrm{S}\end{array}$} & \multirow{3}{*}{ TK } & \multicolumn{9}{|c|}{ Pendekatan Pembelajaran } & \multirow{2}{*}{\multicolumn{3}{|c|}{ Total }} \\
\hline & & \multicolumn{3}{|c|}{ BMJ } & \multicolumn{3}{|c|}{ BM } & \multicolumn{3}{|c|}{ KV } & & & \\
\hline & & $\bar{X}$ & $\mathrm{Sd}$ & $\mathrm{n}$ & $\bar{X}$ & $\mathrm{Sd}$ & $\mathrm{n}$ & $\bar{X}$ & sd & $\mathrm{n}$ & $\overline{\bar{X}}$ & $\mathrm{sd}$ & $\mathrm{n}$ \\
\hline \multirow{4}{*}{$\mathrm{T}$} & $\mathrm{T}$ & 143,07 & 25,98 & 15 & 137,67 & 11,26 & 12 & 133,27 & 10,63 & 11 & 138,53 & 13,48 & 38 \\
\hline & $S$ & 138,30 & 6,87 & 20 & 126,75 & 14,34 & 20 & 116,78 & 7,64 & 23 & 126,78 & 13,35 & 63 \\
\hline & $\mathrm{R}$ & 141,20 & 9,42 & 5 & 130,33 & 6,46 & 9 & 126,75 & 12,61 & 8 & 131,50 & 10,84 & 22 \\
\hline & SBT & 140,45 & 11,35 & 40 & 130,73 & 12,78 & 41 & 123,00 & 11,78 & 42 & 131,25 & 13,88 & 123 \\
\hline \multirow{4}{*}{$S$} & $\mathrm{~T}$ & 136,36 & 15,99 & 11 & 129,29 & 8,22 & 7 & 116,50 & 15,10 & 8 & 128,35 & 15,99 & 26 \\
\hline & $\mathrm{S}$ & 134,15 & 7,70 & 20 & 123,73 & 8,89 & 26 & 107,72 & 9,76 & 25 & 121,03 & 13,86 & 71 \\
\hline & $\mathrm{R}$ & 131,43 & 7,78 & 7 & 116,29 & 10,55 & 7 & 99,25 & 2,91 & 8 & 114,91 & 15,39 & 22 \\
\hline & SBT & 134,29 & 10,60 & 38 & 123,40 & 9,67 & 40 & 107,78 & 11,33 & 41 & 121,50 & 15,13 & 119 \\
\hline \multirow{4}{*}{$\mathrm{R}$} & $\mathrm{T}$ & 127,00 & 7,01 & 8 & 119,00 & 7,62 & 7 & 100,20 & 3,27 & 5 & 117,5 & 12,50 & 20 \\
\hline & $S$ & 127,25 & 10,57 & 24 & 119,43 & 9,61 & 21 & 102,40 & 9,35 & 24 & 116,10 & 14,54 & 69 \\
\hline & $\mathrm{R}$ & 108,71 & 11,04 & 7 & 112,91 & 15,29 & 11 & 94,10 & 3,78 & 10 & 105,14 & 13,84 & 28 \\
\hline & SBT & 123,87 & 12,14 & 39 & 117,51 & 11,31 & 39 & 99,77 & 8,32 & 39 & 113,72 & 14,76 & 117 \\
\hline \multirow{4}{*}{$\begin{array}{l}\mathrm{T} \\
\mathrm{T}\end{array}$} & $\mathrm{T}$ & 137,12 & 15,40 & 34 & 130,38 & 12,17 & 26 & 120,79 & 17,13 & 24 & 130,37 & 16,29 & 84 \\
\hline & $S$ & 132,86 & 9,74 & 64 & 123,28 & 11,21 & 67 & 108,72 & 10,73 & 72 & 121,14 & 14,53 & 203 \\
\hline & $\mathrm{R}$ & 125,63 & 16,50 & 19 & 119,59 & 13,79 & 27 & 105,73 & 16,15 & 26 & 116,18 & 17,29 & 72 \\
\hline & Tot. & 132,92 & 13,23 & 117 & 123,99 & 12,48 & 120 & 110,46 & 14,32 & 122 & 122,30 & 16,23 & 359 \\
\hline
\end{tabular}

Skor Maksimum $180 \quad(\mathrm{BMJ}=$ Berbasis Masalah dengan setting kooperatif tipe Jigsaw, BM = Berbasis Masalah dan KV = Konvensional)

Untuk melihat apakah pendekatan pembelajaran dan level sekolah memberi pengaruh yang signifikan atau tidak terhadap kemandirian belajar siswa dalam matematika serta untuk melihat ada tidaknya interaksi antara level sekolah dan pendekatan pembelajaran terhadap kemampuan kemandirian belajar siswa dalam matematika maka digunakan Anova dua jalur. Hasil pengolahan data dengan menggunakan Anova dua jalur disajikan pada Tabel 2. 
Tabel 2

Rangkuman Uji Anova Dua Jalur Kemandirian Belajar Siswa dalam Matematika dengan Faktor Pendekatan

Pembelajaran dan Level Sekolah

\begin{tabular}{|c|c|c|c|c|c|c|}
\hline Sumber & $\begin{array}{c}\text { Jumlah } \\
\text { Kuadrat }\end{array}$ & $\mathrm{dk}$ & $\begin{array}{c}\text { Rata-rata } \\
\text { Kuadrat }\end{array}$ & $\mathrm{F}$ & Sign & $\mathrm{H}_{\mathrm{o}}$ \\
\hline Pendekatan & 31254,40 & 2 & 15627,20 & 126,39 & 0,00 & Tolak \\
\hline Sekolah & 18803,04 & 2 & 9401,52 & 76,04 & 0,00 & Tolak \\
\hline Interaksi & 1496,34 & 4 & 374,09 & 3,03 & 0,02 & Tolak \\
\hline
\end{tabular}

Untuk melihat apakah pendekatan pembelajaran dan tingkat kemampuan awal siswa (TKAS) memberi pengaruh yang signifikan atau tidak terhadap kemandirian belajar siswa dalam matematika serta untuk melihat ada tidaknya interaksi pendekatan pembelajaran dan TKAS terhadap kemandirian belajar siswa dalam matematika maka digunakan Anova dua jalur. Hasil pengolahan data dengan menggunakan Anova dua jalur disajikan pada Tabel 3.

Tabel 3

\section{Rangkuman Uji Anova Dua Jalur Kemandirian Belajar Siswa dengan Faktor Pendekatan dan TKAS}

\begin{tabular}{|c|c|c|c|c|c|l|}
\hline Sumber & $\begin{array}{c}\text { Jumlah } \\
\text { Kuadrat }\end{array}$ & $\mathrm{dk}$ & $\begin{array}{c}\text { Rata-rata } \\
\text { Kuadrat }\end{array}$ & $\mathrm{F}$ & Sign & $\mathrm{H}_{\mathrm{o}}$ \\
\hline Pendekatan & 19520,49 & 2 & 9760,25 & 59,84 & 0,000 & Ditolak \\
\hline TKAS & 6239,89 & 2 & 3119,94 & 19,13 & 0,000 & Ditolak \\
\hline Interaksi & 673,12 & 4 & 2168,28 & 1,03 & 0,118 & Diterima \\
\hline
\end{tabular}

Dari Tabel 1, 2 dan 3 didapat hasil sebagai berikut:

1) Secara keseluruhan kemandirian belajar siswa termasuk kategori sedang (122,30 dari 180). Ditinjau dari pembelajaran, siswa pada BMJ $(132,92)$ mencapai kemandirian belajar lebih baik dari siswa pada BM $(123,99)$ dan siswa pada KV $(110,46)$. Temuan ini menunjukkan pembelajaran BMJ lebih unggul dibandingkan dengan pembelajaran $\mathrm{BM}$ dan pembelajaran $\mathrm{KV}$ dalam mengembangkan kemandirian belajar siswa.

2) Pada tiap jenis pembelajaran, makin tinggi level sekolah ditemukan makin tinggi pula kemandirian belajar siswa $(140,45,134,29,123,87$, pada BMJ; 130,73, 123,40, 117,51, pada BM; dan 123,00, 107,78, 99,77, pada KV). Temuan tersebut menunjukkan bahwa level sekolah memberikan peran yang baik terhadap pencapaian kemandirian belajar siswa. Demikian pula secara keseluruhan $(113,72,130,37,121,14)$, pada tiap level sekolah $(131,25,121,50$, $113,72)$ dan tiap jenis pembelajaran $(137,12,132,86,125,63$ pada BMJ; 130,38, $123,28,119,59$ pada BM, dan $120,79,108,72$, 105,73 pada KV) makin tinggi kemampuan awal (TKAS) makin tinggi pula kemandirian belajar siswa. Temuan tersebut menunjukkan bahwa TKAS berperan baik terhadap pencapaian 
kemandirian belajar siswa. Ditinjau pada tiap level sekolah, ditemukan bahwa siswa dengan pembelajaran BMJ (140,45, 130,73, 123,00 pada sekolah level tinggi) semuanya mencapai kemandirian belajar lebih baik dari siswa yang memperoleh BM dan KV. Temuan ini menunjukkan bahwa BMJ memberikan pengaruh yang paling besar dibandingkan pembelajaran $\mathrm{BM}$, dan pembelajaran KV, dan level sekolah terhadap pencapaian kemandirian belajar siswa. Namun pada level sekolah tinggi dan level sekolah rendah pada tiap jenis pembelajaran, peranan TKAS terhadap pencapaian kemandirian belajar tidak konsisten.

3) Melalu uji ANOVA dua jalur dan uji Scheffe, terdapat interaksi antara pendekatan pembelajaran dengan level sekolah terhadap KBMTT siswa, dan tidak terdapat interaksi antara pembelajaran dengan TKAS terhadap KBMTT (Tabel 3, Tabel 4, Gambar 1, dan Gambar 2)

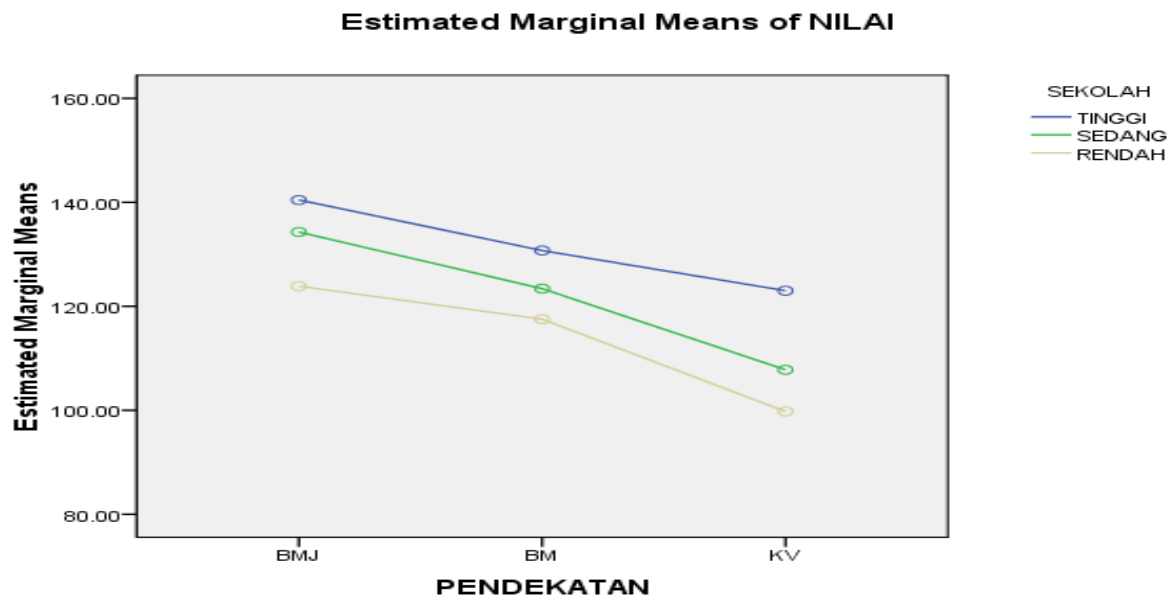

Gambar 1. Interaksi antara Pendekatan Pembelajaran dengan Level Sekolah TerhadapKemandirian Belajar siswa 


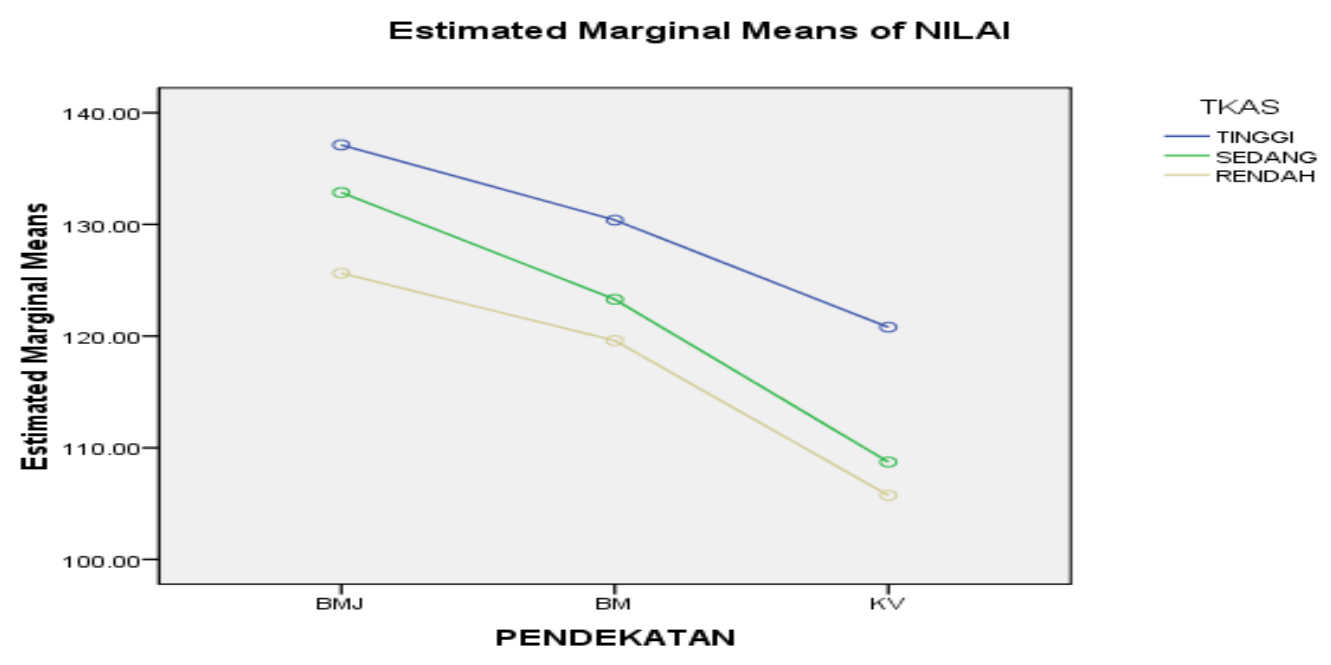

Bagan 2. Interaksi pendekatan pembelajaran dan TKAS terhadap Kemandirian belajar siswa

\section{Kesimpulan dan Saran}

\section{A. Kesimpulan}

Berdasarkan analisis data dan pembahasan yang telah dikemukakan pada bab sebelumnya, diperoleh beberapa kesimpulan sebagai berikut:

1. Kemandirian belajar siswa dalam matematika yang pembelajarannya menggunakan pendekatan Berbasis Masalah dengan setting kooperatif tipe Jigsaw lebih baik daripada yang menggunakan pendekatan Berbasis Masalah maupun konvensional. Demikian pula kemandirian belajar siswa yang memperoleh pembelajaran dengan pendekatan Berbasis Masalah lebih baik daripada kemandirian belajar siswa yang mendapat pendekatan pembelajaran Konvensional dilihat dari level sekolah dan tingkat kemampuan awal siswa (TKAS)

2. Kemandirian belajar siswa yang pembelajaran menggunakan pendekatan Berbasis Masalah dengan setting kooperatif tipe Jigsaw, Berbasis Masalah dan Konvensional berada dalam kualifikasi sedang .

3. Terdapat interaksi antara pendekatan pembelajaran dengan peringkat sekolah terhadap kemandirian belajar siswa dalam matematika. Berarti secara bersamaan faktor pendekatan pembelajaran dan peringkat sekolah memberikan pengaruh yang signifikan terhadap kemandirian belajar siswa. Pendekatan pembelajaran memberikan peran yang signifikan pada penigkatan kemandirian belajar siswa dalam matematika. 
4. Tidak terdapat interaksi antara pendekatan pembelajaran dengan tingkat kemampuan awal matematika siswa terhadap kemandirian belajar siswa . Faktor pendekatan Pembelajaran lebih berperan daripada faktor tingkat kemampuan awal siswa (TKAS), dan peringkat sekolah dalam menghasilkan kemandirian belajar siswa.dalam matematika.

\section{B. Saran}

Berdasarkan implikasi dari penelitian ini, selanjutnya dikemukakan saran-saran sebagai berikut:

3. Pembelajaran dengan pendekatan Berbasis Masalah dengan setting kooperatif tipe Jigsaw hendaknya dijadikan alternatif pendekatan pembelajaran di sekolah terutama untuk siswa sekolah peringkat tinggi dan sedang dalam pembelajaran topik-topik tertentu terutama topik-topik baru yang berkaitan dengan topik-topik sebelumnya yang sudah dipelajari siswa, sehingga pembelajaran matematika menjadi lebih bermakna.

4. Untuk penelitian selanjutnya hendaknya diteliti penggunaan pendekatan Berbasis Masalah dengan setting kooperatif tipe Jigsaw yang diaplikasikan dengan program-program komputer dengan penyajian gambar yang lebih menarik perhatian siswa.

\section{DAFTAR PUSTAKA}

Ratnaningsih, N. (2007). Pengaruh Pembelajaran Kontekstual terhadap Kemampuan Berpikir Kritis dan Kreatif Matematik serta Kemandirian Belajar Siswa Sekolah Menengah Atas. Disertasi. UPI Bandung : Tidak Dipublikasikan.

Sumarmo, U. (2004). Kemandirian Belajar : Apa, Mengapa, dan Bagaimana Dikembangkan pada Peserta Didik. Laporan Penelitian Hibah Pascasarjana UPI. Bandung : Tidak dipublikasikan. 